\title{
Koordinasi Badan Penanggulangan Bencana Daerah dalam Menanggulangi Bencana di Kabupaten Purworejo
}

\section{Coordination of Regional Disaster Management Agencies in Disaster Management in Purworejo District}

\author{
Vira Amalia Bakti' dan Fadlurrahman² \\ 1viraamallia7@gmail.com \\ Jurusan IImu Administrasi Negara, Universitas Tidar \\ Jl. Kapten Suparman 39, Magelang Utara, Jawa Tengah 56116 \\ 2fadlurrahman@untidar.ac.id \\ Jurusan IImu Administrasi Negara, Universitas Tidar \\ Jl. Kapten Suparman 39, Magelang Utara, Jawa Tengah 56116
}

Naskah diterima: 13 April 2020 | Naskah direvisi: 12 Oktober 2020 | Naskah diterbitkan: 31 Desember 2020

\begin{abstract}
Purworejo Regency is the second-highest disaster-prone area in Central Java Province. From the 494 villages and sub-districts in Purworejo Regency, around $90 \%$ are areas prone to natural disasters such as typhoons, landslides, and floods. One of the efforts in disaster management is coordination between stakeholders. On this basis, this study aims to analyze the coordination of the Regional Disaster Management Agency (BPBD) of Purworejo Regency and to find out the factors that encourage successful coordination between BPBD and other institutions in disaster management. The approach used is a qualitative method, with data collection techniques by interview, observation, and documentation. The informant selection technique used was purposive sampling with four informants. The results showed that coordination of $B P B D$ of Purworejo Regency in the pre, during, and the post-disaster condition is good enough to overcome the disasters seen through the basic coordination mechanism (vertical and horizontal). However, coordination still faces obstacles, for example, there are community and private organizations that do not coordinate with the BPBD of Purworejo Regency during disasters. The factors that drive successful coordination are to include meeting forums (physical and non-physical), transparency in decision making, evaluation with stakeholders, and the use of decentralization for stakeholders.
\end{abstract}

Keywords: BPBD of Purworejo Regency; disaster coordination; disaster management

Abstrak: Kabupaten Purworejo merupakan daerah rawan bencana tertinggi kedua di Provinsi Jawa Tengah. Dari 494 desa dan kelurahan di Kabupaten Purworejo, sekitar 90\% merupakan daerah rawan bencana alam seperti puting beliung, tanah longsor, dan banjir. Salah satu usaha dalam manajemen penanggulangan bencana yakni melakukan koordinasi antarpihak. Atas dasar tersebut, studi ini bertujuan untuk menganalisis koordinasi Badan Penanggulangan Bencana Daerah (BPBD) Kabupaten Purworejo serta mengetahui faktor-faktor pendorong keberhasilan koordinasi antara BPBD dengan instansi/lembaga lainnya dalam penanggulangan bencana. Pendekatan yang digunakan yaitu kualitatif dengan metode pengumpulan data secara wawancara, observasi, dan dokumentasi. Pemilihan informan dilakukan dengan menggunakan 
teknik purposive sampling, dengan jumlah informan sebanyak empat orang. Hasil penelitian menunjukkan bahwa koordinasi BPBD Kabupaten Purworejo pada kondisi pra, saat, dan pascabencana sudah cukup baik untuk menanggulangi bencana, yang terlihat melalui mekanisme dasar koordinasi (vertikal dan horizontal). Namun koordinasi masih mengalami hambatan, misalnya: adanya organisasi masyarakat dan pihak swasta yang tidak melakukan koordinasi dengan BPBD saat terjadi bencana. Faktorfaktor pendorong keberhasilan koordinasi di antaranya: adanya forum pertemuan (fisik dan nonfisik), transparansi dalam penciptaan keputusan, evaluasi secara bersama para pihak, dan dukungan desentralisasi penanganan bencana di setiap instansi sesuai dengan standar operasional prosedur (SOP) masing-masing pihak.

Kata Kunci: BPBD Kabupaten Purworejo, koordinasi bencana, penanggulangan bencana

\section{Pendahuluan}

Indonesia merupakan negara yang memiliki wilayah terdampak potensi bencana cukup banyak seperti banjir, tanah longsor, gunung meletus, kekeringan, gempa bumi, dan tsunami (Saputra, 2018: 2). Bahkan, berdasarkan data yang dikeluarkan Badan Perserikatan Bangsa-Bangsa untuk Strategi Internasional Pengurangan Risiko Bencana (UN-ISDR) Indonesia menjadi negara yang paling rawan terhadap bencana ("Indonesia Negara Rawan Bencana," 2011). Hampir di setiap wilayah Indonesia berpotensi terjadi bencana alam, termasuk Kabupaten Purworejo. Berdasarkan data Badan Nasional Penanggulangan Bencana (BNPB) mengenai Indeks Risiko Bencana Indonesia (IRBI) tahun 2013-2018, Kabupaten Purworejo berada pada urutan ke-18 dari total 496 kabupaten/kota se-Indonesia dengan skor IRBI 215, dan masuk sebagai wilayah kategori risiko tinggi. Bahkan, Kabupaten Purworejo menduduki urutan kedua dari 35 kabupaten/kota se-provinsi Jawa Tengah sebagai daerah rawan bencana (Heksantoro, 2018; Wicaksono, 2020). Sekitar 90\% dari 494 desa dan kelurahan di Kabupaten Purworejo merupakan daerah rawan bencana seperti puting beliung, tanah longsor, dan banjir (Gus, 2017). Tingginya risiko bencana di Kabupaten Purworejo dinilai juga dari keunikan bencana yang dialami, yakni banjir dan tanah longsor terjadi dengan serentak. Kenyataan tersebut menjadikan
Kabupaten Purworejo sebagai daerah yang dikategorikan dalam kelas risiko tinggi rawan bencana alam.

Tingginya tingkat bencana alam di Kabupaten Purworejo berdampak pada banyaknya jumlah korban jiwa akibat bencana alam. Data BNPB menunjukkan bahwa dari tahun 2015-2018, total keseluruhan bencana alam yang terjadi di Kabupaten Purworejo mencapai 73 kejadian dengan lima jenis bencana, yaitu banjir, tanah longsor, puting beliung, gelombang pasang, dan kekeringan. Total korban jiwa (meninggal dan hilang, lukaluka, menderita, dan mengungsi) akibat bencana alam dalam kurun waktu tersebut mencapai 15.353 jiwa (Tabel 1). Belum lagi ditambah dengan rusaknya rumah warga dan infrastruktur (fasilitas umum) yang dialami sebagai dampak adanya bencana alam. Dengan demikian, dapat dikatakan bahwa bencana alam di Kabupaten Purworejo tidak dapat dihindari. Namun, dampak yang ditimbulkan, khususnya korban jiwa, dapat diminimalisir dengan melakukan penanggulangan bencana yang baik.

Salah satu upaya penanggulangan bencana yaitu dengan mengurangi risiko bencana. Saat ini, paradigma pengurangan risiko bencana berorientasi pada masyarakat sebagai subjek, bukan sebagai objek (Kurniawati, 2015: 100). Amran (2016: 140) mengungkapkan bahwa pengurangan risiko bencana merupakan suatu pendekatan yang pada dasarnya 
Tabel 1.

Jenis Bencana Alam dan Total Korban Jiwa

di Kabupaten/Kota Purworejo, Tahun 2015-2018

\begin{tabular}{lccrrrr}
\hline \multirow{2}{*}{ Jenis Bencana } & \multicolumn{5}{c}{ Tahun } & \multirow{2}{*}{ Total } \\
\cline { 2 - 5 } & $\mathbf{2 0 1 5}$ & $\mathbf{2 0 1 6}$ & $\mathbf{2 0 1 7}$ & $\mathbf{2 0 1 8}$ & \\
\hline Banjir & 3 & 3 & 5 & 0 & 11 \\
Tanah longsor & 9 & 7 & 13 & 9 & 38 \\
Puting beliung & 1 & 5 & 13 & 3 & 22 \\
Gelombang pasang & 0 & 0 & 0 & 1 & 1 \\
Kekeringan & 0 & 0 & 0 & 1 & 1 \\
\hline Total bencana per tahun & 13 & 15 & 31 & 14 & 73 \\
\hline Total korban jiwa per tahun & 3.245 & 2.530 & $\mathbf{1 . 5 6 1}$ & $\mathbf{8 . 0 1 7}$ & 15.353 \\
\hline
\end{tabular}

Sumber: BNPB, 2015-2018

berusaha untuk mengurangi kerentanan sosial ekonomi masyarakat terhadap bencana secara sistematis yang menjadi tanggung jawab bersama, khususnya pemerintah. Berkaitan dengan hal tersebut, maka pengurangan risiko bencana harus dikomando oleh Pemerintah dengan melibatkan berbagai pihak. BNPB selaku komando penanggulangan bencana di tingkat pusat memiliki perwakilan di setiap daerah, yaitu Badan Penanggulangan Bencana Daerah (BPBD) Provinsi dan Kabupaten. Pembentukan BPBD mengacu pada Undang-Undang Nomor 24 Tahun 2007 tentang Penanggulangan Bencana, dan berfungsi sebagai lembaga pelaksana penanggulangan bencana di daerah dengan tugas pengkoordinasian dan pelaksanaan kegiatan penanggulangan bencana secara terencana, terpadu, dan menyeluruh (Undang-Undang tentang Penanggulangan Bencana, 2007). Kemudian dalam Peraturan Kepala Badan Nasional Penanggulangan Bencana (BNPB) Nomor 4 Tahun 2008 tentang Perencanaan Penanggulangan Bencana, disebutkan juga bahwa untuk menanggulangi bencana perlu adanya koordinasi eksternal kelembagaan dengan instansi terkait penanggulangan bencana. Koordinasi yang dilakukan baik secara internal maupun eksternal kelembagaan bekerja sama dengan instansi/lembaga lain yang memiliki fungsi yang sama, seperti palang merah Indonesia (PMI), tentara nasional Indonesia (TNI), polisi Republik Indonesia (POLRI), Dinas Sosial, Dinas Kesehatan, lembaga swadaya masyarakat (LSM), pihak swasta, dan civil society (Peraturan Kepala BNPB tentang Perencanaan Penanggulangan Bencana, 2008).

Kajian koordinasi lembaga merupakan isu penting dalam tataran penanggulangan bencana alam guna memberikan informasi ataupun pembelajaran kepada lembaga-lembaga terkait untuk lebih meningkatkan kapasitas sumber daya maupun mengatasi kelemahan sistem yang ada. Dalam praktiknya, koordinasi merupakan tantangan utama di antara individu, kelompok, dan organisasi dalam rangka merespons bencana (Bahadori, Khankeh, Zaboli, \& Malmir, 2015: 274). Beberapa penelitian yang fokus pada penanggulangan bencana mengatakan bahwa koordinasi lembaga yang baik akan menghasilkan tujuan dan mencapai sasaran secara efektif, mengembangkan kapasitas lokal, meningkatkan keterlibatan partisipan, dan mencegah dampak berkelanjutan (Ramdani, 2015: 388; Yoseph-Paulus \& Hindmarsh, 2016: 2; Horney, Nguyen, Salvesen, Tomasco, \& Berke, 2016: 33). Sebaliknya, lemahnya koordinasi antarlembaga berpotensi menyebabkan kegagalan pencapaian sasaran dalam penanggulangan bencana. 
Kajian penanggulangan bencana telah dilakukan oleh para peneliti, baik nasional maupun internasional, dengan mencakup beberapa aspek, misalnya pada aspek manajemen (Guo \& Kapucu, 2015: 201), implementasi (Putra, 2015: 5), pola komunikasi (Lubis \& Wahyudi, 2016: 1), koordinasi dan pengembangan kapasitas (Yoseph-Paulus \& Hindmarsh, 2016: 2), dan public engage (Horney et al., 2016: 33). Namun demikian, penelitian-penelitian tersebut tidak menyentuh aspek koordinasi secara lengkap. Sementara itu, dalam penelitian ini berusaha mengeksplorasi koordinasi penanggulangan bencana secara vertikal dan horizontal, mekanisme dasar, serta faktor pendorong keberhasilan koordinasi. Dengan demikian, penelitian ini dapat dikatakan mengisi gap dari penelitian-penelitian terdahulu.

Berkaitan dengan koordinasi kelembagaan dalam penanggulangan bencana, penelitian ini dilakukan atas tiga dasar landasan: pertama, tingginya tingkat bencana di Kabupaten Purworejo sehingga menarik perhatian peneliti untuk mengkaji lebih dalam mengenai kegiatan penanggulangan bencana oleh BPBD Kabupaten Purworejo, khususnya fokus pada koordinasi lembaga. Kedua, dengan intensitas kejadian bencana alam yang tinggi, BPBD Kabupaten Purworejo berhasil menanggulangi bencana hingga mendapat penghargaan dari BNPB sebagai BPBD terbaik di wilayah 2 (Jawa, Bali, dan Kalimantan) pada tingkat kabupaten/kota pada tahun 2018 (Saut, 2018). Ketiga, koordinasi lembaga merupakan salah satu usaha yang memengaruhi keberhasilan maupun kegagalan dalam penanggulangan bencana. Maka dari itu, analisis koordinasi lembaga akan menghasilkan sebuah kajian yang bermanfaat, baik secara akademis maupun praktis, serta dapat digunakan sebagai lesson learn bagi pihak-pihak yang membutuhkan.

Atas dasar tersebut, maka pertanyaan utama dalam penelitian ini adalah bagaimana koordinasi BPBD Kabupaten
Purworejo dalam menanggulangi bencana? Adapun tujuan penelitian ini yaitu menganalisis koordinasi BPBD Kabupaten Purworejo dalam penanggulangan bencana dengan mengkaji tiga aspek utama, di antaranya: koordinasi vertikal dan koordinasi horizontal, analisis mekanisme dasar koordinasi, dan faktor pendorong keberhasilan koordinasi. Kerangka teoritis yang diacu terkait aspek-aspek penelitian ini yaitu: (1) koordinasi vertikal dan koordinasi horizontal mengacu pada Octorano (2015: 110), analisis koordinasi vertikal dan horizontal akan melihat alur komunikasi antarlembaga; (2) mekanisme dasar koordinasi mengacu pada Stoner dan Freeman (1992: 234), analisis mekanisme dasar dilihat dari hierarki manajemen, peraturan, dan prosedur, serta perencanaan dan penetapan tujuan; (3) faktor pendorong keberhasilan mengacu pada Achyar, Schmidt-Vogt, dan Shivakoti (2015: 16), analisis faktor pendorong dilihat dari ketersediaan forum, transparansi keputusan, evaluasi kegiatan, dan desentralisasi dalam pelaksanaan kegiatan.

Metode penelitian yang digunakan adalah metode deskriptif dengan pendekatan kualitatif. Objek kajiannya yaitu koordinasi pelaksanaan penanggulangan bencana. Informan dalam penelitian ini dipilih menggunakan teknik purposive sampling yang berjumlah empat orang informan. Adapun informan penelitian berasal dari empat lembaga di Kabupaten Purworejo yang saling berkaitan dalam koordinasi penanggulangan bencana, di antaranya: Badan Penanggulangan Bencana Daerah Kabupaten Purworejo; Palang Merah Indonesia Kabupaten Purworejo; Dinas sosial, Pengendalian Penduduk, Keluarga Berencana, Pemberdayaan Perempuan, dan Perlindungan Anak Kabupaten Purworejo; dan Komando Distrik Militer (KODIM) 0708 Kabupaten Purworejo.

Pengumpulan data menggunakan
metode atau teknik wawancara,


observasi, dan dokumentasi. Wawancara dilakukan secara terstruktur kepada para informan dalam penelitian ini dengan memberikan beberapa pertanyaan seperti bagaimana koordinasi (secara vertikal dan horizontal) Badan Penanggulangan Bencana Daerah Kabupaten Purworejo dengan lembaga/instansi yang turut menanggulangi bencana? bagaimana mekanisme koordinasi dilaksanakan untuk mencapai efektivitas koordinasi? dan bagaimana faktor pendorong koordinasi memberikan kontribusi dalam kelancaran koordinasi antarlembaga?. Observasi meliputi pengamatan kegiatan koordinasi antarlembaga, berupa rapat rutin di mana penulis sebagai pengamat nonpartisipan. Dokumentasi meliputi kegiatan pengumpulan dokumen-dokumen yang berkaitan dengan kajian yang diteliti berupa gambar-gambar atau foto-foto pendukung, seperti gambar struktur organisasi, foto alat pendukung koordinasi, dan foto kegiatan rapat rutin koordinasi antarlembaga. Selanjutnya, teknik analisis data terdiri dari pengumpulan data, reduksi data, penyajian data, dan penarikan kesimpulan (Sugiono, 2014: 206).

\section{Tinjauan Koordinasi Kelembagaan}

Organisasi merupakan wadah
bagi sekelompok orang yang memiliki kepentingan tertentu, memiliki visi dan tujuan yang sama, dan berbagai macam kegiatan untuk mencapai tujuan tersebut. Secara umum, organisasi memiliki beberapa ciri atau karakteristik, di antaranya: tujuan umum bersama, pembagian kerja, hierarki otoritas, dan koordinasi upaya (Wijaya, 2017: 6). Di dalam organisasi akan terjadi interaksi antaranggota yang tentunya memiliki perbedaan tugas, wewenang, dan kewajiban. Guna menyelaraskan perbedaan-perbedaan tersebut, perlu diadakan koordinasi agar berjalan sesuai dengan rencana yang telah disepakati secara bersama. Koordinasi dalam organisasi sangatlah penting untuk dilakukan, terlebih lagi apabila sasaran dan tujuan yang akan dicapai begitu kompleks sehingga dibutuhkan jaringan hubungan kerja yang kompleks pula.

Koordinasi merupakan suatu usaha yang berfungsi untuk mengarahkan pelaksanaan suatu kegiatan guna menghasilkan suatu tindakan yang seragam dan harmonis sesuai dengan sasaran dan tujuan yang telah ditentukan (Sukarno, 2016: 218). Sama halnya dengan pendapat di atas, Hustedt dan Danken (2017: 2) mendefinisikan koordinasi sebagai kegiatan pengaturan dan penyesuaian terhadap tindakan dan keputusan di antara berbagai aktor yang terlibat dalam rangka mencapai tujuan tertentu. Mengacu pada kedua pendapat di atas, dapat dikatakan bahwa koordinasi sesungguhnya memiliki fungsi yang teramat penting bagi setiap organisasi (apapun bentuknya), karena koordinasi merupakan salah satu prinsip yang harus dipegang teguh oleh organisasi (Wijaya, 2017: 223-224). Koordinasi dapat memberikan beberapa manfaat bagi organisasi, seperti memperkuat hubungan antarsatuan-satuan dan antarpejabat; menghindari pendapat bahwa satuan organisasi atau pejabat merupakan yang paling penting; menghindari kemungkinan timbulnya pertentangan antarunit; menghindari terjadinya kekosongan pekerjaan; dan memunculkan kesadaran untuk saling membantu (Octorano, 2015: 110). Tanpa adanya koordinasi, maka perencanaan telah ditetapkan dan tujuan dari kegiatan yang diselenggarakan akan sulit tercapai. Bahkan berpotensi mengalami kegagalan, atau paling tidak capaian tersebut jauh dari kata sempurna karena ketiadaan harmonisasi dan penyesuaian langkah apa yang akan dilakukan selanjutnya. Seperti yang dikatakan Stoner dan Freeman (1992: 200) yakni "tanpa koordinasi, setiap individu/ departemen akan kehilangan pedoman atau pegangan kerja tentang apa yang harus dilaksanakan". 
Koordinasi memiliki dua bentuk subkategori (Kaynak \& Tuger, 2014: 433; Octorano, 2015; 110): pertama, koordinasi vertikal yang berarti komunikasi antarindividu/unit dalam satu lembaga (internal) atau antarlembaga (eksternal) secara garis lurus dari atas ke bawah dan/ atau dari bawah ke atas. Dalam koordinasi vertikal mengandung hierarki komando antara atasan dan bawahan. Umumnya, koordinasi vertikal mudah untuk dilakukan karena struktur hierarki sudah jelas. Kedua, koordinasi horizontal, yaitu komunikasi antarindividu/unit dalam lembaga (internal) atau antarlembaga (eksternal) yang memiliki posisi sama (setingkat). Koordinasi horizontal bisa terjadi pada lembaga yang memiliki fungsi sama (interdisciplinary) ataupun pada lembaga yang memiliki fungsi berbeda (interrelated). Namun posisi (tingkatan) lembaga tersebut tidak berbeda, atau dengan kata lain tidak mengandung hierarki. Koordinasi horizontal relatif sulit dilakukan, khususnya pada unit atau lembaga yang kedudukannya setingkat dikarenakan tidak memiliki hierarki otoritas yang tegas. Permasalahan-permasalahan juga kerap muncul dalam koordinasi horizontal karena adanya kepentingan yang berbeda dari masing-masing unit atau lembaga (Husted \& Danken, 2017: 1).

Koordinasi lembaga dapat berjalan secara efektif apabila terdapat mekanisme dasar dalam pelaksanaannya. Mekanisme dasar tersebut mengandung beberapa unsur yang harus diperhatikan, di antaranya (Stoner \& Freeman, 1992: 234): (1) Hierarki manajemen, mencakup garis komando untuk memudahkan arus informasi dan kerja antara unit-unit, komunikasi dan pemantauan, dan penyampaian laporan dari anggota koordinasi. (2) Peraturan dan prosedur, mencakup berbagai peraturan dan standar operasional prosedur (SOP) sebagai alat koordinasi untuk kegiatan yang sifatnya berulang-ulang. (3) Perencanaan dan penetapan tujuan, mencakup pengembangan rencana dan tujuan dalam suatu kegiatan oleh berbagai lembaga/instansi yang terlibat. Dengan mengetahui tujuan masing-masing unit, maka dapat membantu untuk bertindak secara konsisten sesuai dengan tujuan bersama. Kemudian dalam rangka pelaksanaan koordinasi antarlembaga, tentunya terdapat berbagai faktor yang dapat membantu pelaksanaan koordinasi berjalan semakin efektif. Achyar et al. (2015: 16) menyebutkan terdapat empat faktor, di antaranya ketersediaan forum, transparansi keputusan, evaluasi kegiatan, dan desentralisasi dalam pelaksanaan kegiatan.

\section{Koordinasi Vertikal dan Horizontal BPBD Kabupaten Purworejo}

BPBD kabupaten Purworejo merupakan instansi yang secara khusus menangani masalah kebencanaan di kabupaten Purworejo. Berdasarkan Peraturan Bupati Purworejo Nomor 62 Tahun 2012, BPBD kabupaten Purworejo memiliki tugas dan fungsi sebagai lembaga utama dalam penanggulangan bencana daerah dan harus berkoordinasi dengan lembaga pendukung lainnya termasuk kepala daerah. Koordinasi dalam pencapaian tujuan organisasi memiliki peran vital yang tidak bisa diabaikan karena berperan strategis guna meningkatkan kinerja organisasi.

Pada koordinasi vertikal terjadi kegiatan penyatuan dan pengarahan yang diberikan oleh atasan kepada unit-unit dan kesatuan-kesatuan kerja yang berada di bawah wewenang dan tanggung jawab suatu lembaga pemerintah yang memiliki tingkatan tertentu. Dalam hal ini, koordinasi penanggulangan bencana melibatkan beberapa lembaga di antaranya pemerintah Kabupaten Purworejo, BPBD Kabupaten Purworejo, BPBD Provinsi Jawa Tengah, dan BNPB. Alur koordinasi yang dilakukan oleh BPBD Kabupaten Purworejo secara vertikal terdiri dari tiga alur dan 
bersifat timbal balik: (1) koordinasi antara pemerintah Kabupaten Purworejo dan BPBD Kabupaten Purworejo. Koordinasi yang terjalin berada pada domain lokal yang berarti hanya melibatkan pemerintah daerah dan lembaga yang berada di domain otoritas pemerintah daerah tersebut dalam menanggulangi bencana. Koordinasi ini dilakukan sebagai wujud pelaksanaan penanggulangan bencana di daerah, dengan pemerintah Kabupaten Purworejo sebagai unsur pengarah dan BPBD Kabupaten Purworejo sebagai unsur pelaksana. Setelah koordinasi tersebut telah terlaksana, maka dilakukan koordinasi lanjutan antarlembaga khusus yang menangani masalah kebencanaan. (2) Alur koordinasi yang kedua yaitu antara BNPB, BPBD Provinsi Jawa Tengah, dan BPBD Kabupaten Purworejo. Alur koordinasi ini mengandung unsur hierarki yang berurutan, yaitu koordinasi dari BPBD Kabupaten Purworejo kepada BPBD Provinsi Jawa Tengah, kemudian dilanjutkan ke BNPB atau sebaliknya. (3) Alur koordinasi yang ketiga yaitu koordinasi langsung antara BNPB dan BPBD Kabupaten Purworejo. Alur koordinasi ini bersifat khusus dikarenakan BPBD Kabupaten Purworejo tidak perlu berkoordinasi terlebih dahulu kepada BPBD Provinsi Jawa Tengah. Tindakan ini dapat dilaksanakan sesuai dengan prosedur yang berlaku, yakni penembusan

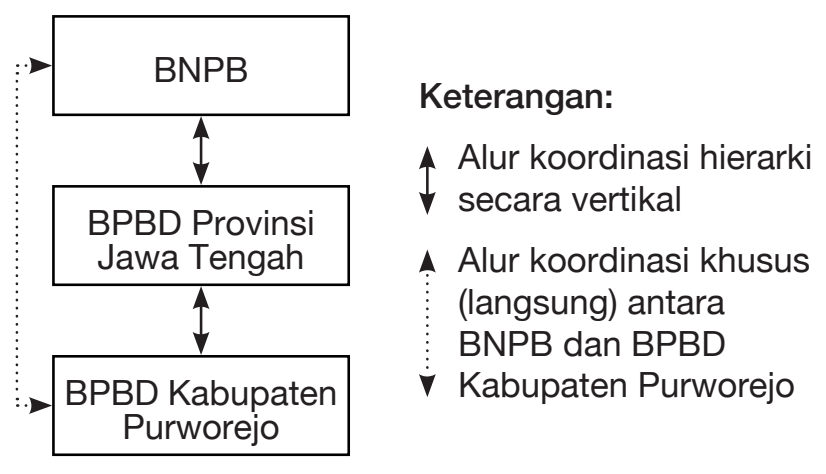

Bagan 1.

Koordinasi Vertikal antara BNPB, BPBD

Provinsi Jawa Tengah, dan BPBD Kabupaten Purworejo

Sumber: Diolah surat dari BPBD Kabupaten Purworejo ke BPBD Provinsi Jawa Tengah. Alur yang ketiga lebih diprioritaskan karena lebih efisien dan cepat. Dalam urusan kebencanaan, segala informasi (arahan dan petunjuk secara vertikal) harus mengalir atau dikoordinasikan secara cepat karena bersifat darurat. Oleh sebab itu, alur ketiga lebih sering dilakukan oleh BPBD Kabupaten Purworejo dalam menangani bencana.

Selanjutnya, koordinasi horizontal yang dilakukan BPBD Kabupaten Purworejo pada saat penanggulangan bencana dilaksanakan dengan melibatkan lembaga/ instansi setingkat yang memiliki kewajiban yang sama dalam tugas kebencanaan, misalnya TNI, POLRI, PMI, LSM, dan OPD yang ada di Kabupaten Purworejo. Pada tataran horizontal, BPBD Kabupaten Purworejo berfungsi sebagai komando atau koordinator penggerak lembaga/ instansi yang lain dalam menanggulangi kejadian bencana alam.

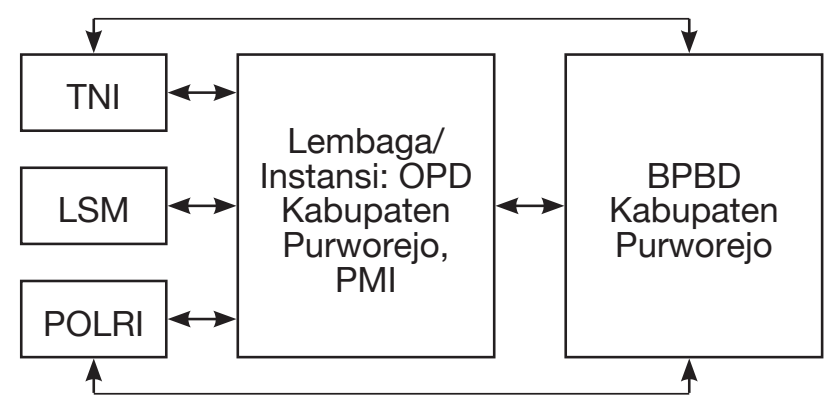

Keterangan:

$\leftrightarrow$ Alur koordinasi secara horizontal (timbal balik)

\section{Bagan 2. \\ Koordinasi Horizontal antar Lembaga di Kabupaten Purworejo \\ Sumber: Diolah}

Koordinasi horizontal memiliki fungsi yang vital, karena berkaitan langsung dengan urusan atau masalah masyarakat saat terjadi bencana. Pada saat di lapangan, lembaga/instansi dan OPD Kabupaten Purworejo bersentuhan langsung dengan masyarakat dalam menanggulangi bencana. Berbagai macam informasi yang masuk dari 
masyarakat, baik secara langsung ke BPBD Kabupaten Purworejo ataupun melalui lembaga/instansi lainnya saat terjadi bencana, akan segera diproses dan dikoordinasikan secara timbal balik kepada lembaga/instansi yang ada. Koordinasi yang terjalin secara horizontal merupakan tindakan pemenuhan kebutuhan masyarakat terdampak bencana dalam konteks penanggulangan bencana. BPBD Kabupaten Purworejo tidak memiliki kelengkapan sumber daya (data, peralatan, obat-obatan, hunian, dan sebagainya) untuk menangani dampak bencana yang dialami masyarakat. Oleh sebab itu, perlu dilaksanakan koordinasi antarlembaga/instansi secara horizontal sebagai bentuk penyeimbangan sumber daya guna memenuhi kebutuhan masyarakat, misalnya berupa hunian atau tempat pengungsian dikoordinasikan dengan Dinas Sosial; terkait kesehatan dikoordinasikan dengan Dinas Kesehatan dan PMI; dan terkait kebutuhan pemenuhan infrastruktur dikoordinasikan dengan Dinas Pekerjaan Umum.

\section{Mekanisme Dasar Koordinasi Penanggulangan Bencana Daerah}

Efektivitas koordinasi penanggulangan bencana dapat tercapai bila memperhatikan unsur-unsur utama, di antaranya hierarki manajemen, peraturan dan prosedur, serta perencanaan dan penetapan tujuan. Pertama, hierarki manajemen mencakup fungsi komando untuk memudahkan arus informasi dan kerja antarunit, baik secara vertikal maupun horizontal. Dalam pelaksanaannya, secara vertikal hierarki manajemen tergambar melalui struktur organisasi BPBD Kabupaten Purworejo yang dipimpin oleh Sekretaris Daerah (ex-officio) dan juga dipimpin oleh kepala pelaksana yang saling berkoordinasi secara rutin. Sekretaris Daerah memimpin BPBD Kabupaten Purworejo pada domain administratif, sedangkan kepala pelaksana memimpin
BPBD Kabupaten Purworejo pada domain yang bersifat teknis dan operasional. Maka dari itu komunikasi terus dilakukan secara rutin antara Sekretaris Daerah (exofficio) dengan kepala pelaksana BPBD Kabupaten Purworejo.

Selain itu, garis komando (vertikal) antara BPBD Kabupaten Purworejo, BPBD Provinsi Jawa Tengah, dan BNPB dilakukan secara rutin dengan memanfaatkan berbagai sarana dan media komunikasi berupa radio, e-mail, telepon satelit ataupun sarana lainnya yang mudah digunakan, baik sebelum, saat, dan setelah terjadinya bencana. Salah satu bentuk hierarki manajemen secara vertikal terjadi pada proses koordinasi bantuan dana kebencanaan pada tahap tanggap darurat dan tahap pascabencana. BPBD Kabupaten Purworejo dapat mengajukan bantuan dana kebencanaan kepada Pemerintah Kabupaten Purworejo terlebih dahulu. Jika pemerintah kabupaten tidak sanggup mendanai, maka pemerintah kabupaten akan melakukan koordinasi lanjutan dengan provinsi terkait bantuan pendanaan melalui Bantuan Gubernur (BanGub). Selain itu, BPBD Kabupaten Purworejo juga dapat mengajukan bantuan dana kebencanaan kepada BNPB bila BantGub masih kurang mencukupi kebutuhan yang bersumber dari dana siap pakai yang dapat digunakan sesuai dengan Peraturan Kepala Badan Nasional Penanggulangan Bencana Nomor 6A Tahun 2011 tentang Pedoman Penggunaan Dana Siap Pakai Pada Status Keadaan Darurat Bencana.

Kemudian pada tataran horizontal, hierarki manajemen atau fungsi komando terlihat pada komunikasi dua arah antara BPBD Kabupaten Purworejo dengan para pihak/lembaga melalui berbagai media, salah satunya media sosial Whatsapp Group. Grup tersebut berisikan semua lembaga yang terlibat dalam penanggulangan bencana. Fungsi grup tersebut yaitu sebagai media untuk memastikan validitas informasi bencana 
yang diterima oleh salah satu lembaga. Apabila terdapat informasi yang masuk ke grup tersebut, maka akan segera di crosscheck oleh lembaga-lembaga lainnya. Kemudian, jika informasi tersebut dinyatakan benar dan valid, maka akan langsung ditindaklanjuti sesuai dengan jenis bencana yang terjadi.

Kedua, peraturan dan prosedur yang merupakan alat koordinasi dalam melaksanakan penanggulangan bencana. BPBD Kabupaten Purworejo menggunakan peraturan dan prosedur yang berpedoman pada Undang-Undang Kebencanaan, Peraturan Kepala BNPB, Peraturan Daerah Kabupaten Purworejo, dan Peraturan Bupati Kabupaten Purworejo. Adapun pihak-pihak lain (Organisasi Perangkat Daerah/OPD, swasta, Lembaga Swadaya Masyarakat/LSM) yang terlibat dalam penanggulangan bencana, memiliki peraturan dan prosedur tersendiri saat terjadinya bencana sesuai dengan tugas pokok dan fungsi (tupoksi) masing-masing pihak. Peraturan dan prosedur yang dimiliki oleh masing-masing pihak hanya berlaku pada domain-domain tertentu. Namun demikian, terdapat pedoman guna menyatukan tindakan semua pihak, yaitu rencana kontingensi yang merupakan dokumen bersama yang disusun sejak tahun 2013 dan diberlakukan tahun 2014. Rencana kontingensi setiap tahun terus dikembangkan dengan menyesuaikan keadaan lingkungan yang terus mengalami perubahan. Secara garis besar dokumen tersebut berisikan 'siapa' berbuat 'apa' sehingga apabila terjadi bencana, semua pihak sudah memahami tupoksinya masing-masing di bawah komando BPBD Kabupaten Purworejo.

Berdasarkan fakta di lapangan, meskipun rencana kontingensi telah diberlakukan namun masih terdapat beberapa permasalahan koordinasi yang berujung pada ketidaktepatan sasaran bantuan bencana serta pendirian pos komando (posko) 'dadakan' yang dikarenakan beberapa pihak di luar badan/ atau lembaga pemerintahan, seperti organisasi masyarakat dan swasta tidak berkoordinasi dengan BPBD Kabupaten Purworejo sebagai komando lapangan. Padahal keberadaan BPBD Kabupaten Purworejo sebagai komando lapangan untuk mempermudah dan memperjelas alur distribusi bantuan bencana agar bantuan tersebut benar-benar tepat sasaran. Kemudian untuk pendirian posko sebetulnya telah diatur dalam Peraturan Kepala BNPB Nomor 14 Tahun 2010 tentang Pedoman Pembentukan Pos Komando Tanggap Darurat Bencana (Perka Pedoman Pembentukan Pos Komando Tanggap Darurat). Dalam pelaksanaannya, terdapat dua posko yaitu posko induk dan posko lapangan. Posko induk dipimpin oleh BPBD Kabupaten Purworejo, sedangkan posko lapangan digerakkan oleh pihak lain yang bertugas menjadi wakil. Pembentukan posko harus mengacu pada Perka Pedoman Pembentukan Pos Komando Tanggap Darurat. Posko yang dibentuk tanpa acuan peraturan yang legal dan tanpa koordinasi dengan BPBD Kabupaten Purworejo tentunya akan menyulitkan dalam pengumpulan data. Peraturan dan prosedur yang berlaku sebagai alat koordinasi kebencanaan mengikat semua pihak, termasuk organisasi masyarakat dan swasta. Peraturan-peraturan tersebut merupakan legalitas bagi BPBD Kabupaten Purworejo untuk mengkoordinir semua pihak.

Ketiga, perencanaan dan penetapan tujuan merupakan unsur terpenting dalam proses penanggulangan bencana. Tanpa perencanaan yang matang, koordinasi kegiatan apapun, sulit untuk dilaksanakan. Berdasarkan data di lapangan, proses perencanaan dan penetapan tujuan penanggulangan bencana diaktualisasikan melalui rapat koordinasi secara rutin antara BPBD Kabupaten Purworejo -sebagai koordinator- dengan pihak-pihak terkait. Melalui rapat koordinasi tersebut, dihasilkan suatu keputusan kebijakan dan 
sebagai sarana meningkatkan komunikasi dan komitmen dalam mencapai tujuan.

Adapun proses kegiatan perencanaan dan penetapan tujuan pada tahap prabencana antara lain membentuk rencana kontingensi yang berisikan kegiatan pembuatan peta rawan bencana. Kemudian melaksanakan perencanaan mitigasi melalui kegiatan sosialisasi kepada masyarakat dan pembentukan desa tangguh bencana. Salah satu produk yang dihasilkan yaitu dokumen rencana kontingensi itu sendiri yang menjadi pedoman bagi semua pihak yang terlibat.

\section{Faktor Pendorong Keberhasilan Koordinasi}

Koordinasi

BPBD

Kabupaten Purworejo dengan berbagai macam pihak/ lembaga dapat dikatakan sudah cukup baik. Namun demikian, bukan berarti tidak memiliki hambatan dalam pelaksanaanya. Hambatan tersebut dapat dijadikan sebagai kesempatan atau peluang untuk menciptakan keberhasilan koordinasi apabila dapat dimanajemen dengan baik. Berdasarkan temuan di lapangan, faktor pendorong keberhasilan dalam melaksanakan koordinasi yaitu peraturan pada tataran vertikal, khususnya koordinasi internal dalam tubuh BPBD Kabupaten Purworejo. Koordinasi mudah untuk dilakukan dikarenakan terdapat sanksi apabila aparat tidak mengikuti peraturan yang berlaku.

Pada tataran horizontal yang melibatkan multi-pihak, terdapat 4 faktor pendorong keberhasilan koordinasi seperti yang diungkapkan oleh Achyar et al., (2015: 16), di antaranya: pertama, ketersediaan forum koordinasi. Dalam melaksanakan koordinasi, BPBD Kabupaten Purworejo memanfaatkan forum yang tersedia baik berupa pertemuan fisik dan nonfisik. Forum tersebut dibentuk khusus untuk melaksanakan koordinasi dengan kegiatan berupa perencanaan, pelaporan, serta sosialisasi penanggulangan bencana dalam bentuk pertemuan fisik berupa rapat koordinasi yang melibatkan pihakpihak terkait. Sementara pertemuan nonfisik, BPBD Kabupaten Purworejo memanfaatkan media sosial berupa Whatsapp Group untuk dijadikan sebagai forum penunjang. Forum ini sangat membantu efektivitas kegiatan dan efisiensi waktu koordinasi. Melalui forum ini juga informasi antaranggota koordinasi dapat dikumpulkan sebagai landasan dalam menetapkan keputusan.

Kedua, transparansi dalam penciptaan keputusan. Proses penciptaan keputusan khususnya dalam konteks penanggulangan bencana, BPBD Kabupaten Purworejo selalu melibatkan stakeholders melalui forum yang ada baik dalam pertemuan fisik maupun nonfisik. Keputusan ataupun kebijakan yang ditetapkan oleh kepala BPBD Kabupaten Purworejo merupakan hasil musyawarah dari semua pihak yang berkepentingan. Dengan begitu, unsur transparansi dalam sebuah keputusan sudah tercipta.

Ketiga, kualitas pembelajaran secara bersama yang diaktualisasikan dalam bentuk evaluasi kegiatan. Pada saat terjadinya bencana atau tanggap darurat, BPBD Kabupaten Purworejo setiap hari melaksanakan evaluasi kegiatan dengan tujuan menilai hasil kerja dari setiap pihak apakah telah sesuai dengan hasil yang diharapkan atau tidak, mencari hambatan dan menentukan solusi. Semua hal tersebut merupakan input yang berguna sebagai bahan pembelajaran dan pertimbangan guna menciptakan dan mengambil keputusan yang tepat.

Keempat, dukungan desentralisasi berupa pemberian wewenang kepada para pihak untuk bergerak sesuai SOP masingmasing pihak. BPBD Kabupaten Purworejo selaku koordinator lapangan menekankan prinsip desentralisasi bagi setiap pihak saat penanganan bencana selama SOP yang digunakan tidak bertentangan dengan aturan yang digunakan oleh BPBD Kabupaten Purworejo. Mengingat kondisi dan situasi lapangan saat terjadi bencana 
sangat dinamis serta setiap pihak juga memiliki tupoksi dan sumber daya yang berbeda-beda, maka prinsip desentralisasi pada saat penanganan bencana harus diberikan seluas-luasnya. Namun dalam pengambilan keputusan harus tetap berkoordinasi dengan BPBD Kabupaten Purworejo untuk menghindari ketidakefektifan kegiatan.

\section{Penutup}

Koordinasi vertikal BPBD Kabupaten Purworejo hanya melibatkan beberapa lembaga yang memiliki otoritas level berbeda (struktur hierarki) di antaranya Pemerintah Kabupaten Purworejo, Badan Nasional Penanggulangan Bencana (BNPB), dan BPBD Provinsi Jawa Tengah. Sementara koordinasi horizontal lebih banyak melibatkan lembaga dengan otoritas level yang sama. Namun demikian, BPBD Kabupaten Purworejo memiliki kewajiban sebagai komando atau koordinator lapangan.

Mekanisme dasar koordinasi sudah dilaksanakan dengan baik, mulai dari hierarki manajemen yang tergambar pada koordinasi vertikal, peraturan, dan prosedur yang ditaati oleh BPBD Kabupaten Purworejo (meskipun terdapat beberapa pihak yang 'abai' terhadap prosedur dan aturan bersama), hingga perencanaan dan penetapan tujuan yang dibentuk untuk meminimalisir dampak negatif dari adanya bencana. Kemudian keberhasilan koordinasi BPBD Kabupaten Purworejo dalam penanggulangan bencana didorong oleh empat faktor yang berhasil diidentifikasi, di antaranya ketersediaan forum (fisik dan nonfisik), transparansi keputusan, evaluasi kegiatan secara bersama, dan dukungan desentralisasi bagi setiap pihak.

Beberapa saran yang diberikan antara lain: pertama, secara hierarki manajemen, BPBD Kabupaten Purworejo dipimpin oleh dua pimpinan yang bergerak pada dua ranah berbeda, yakni pada tataran administratif dan operasional atau teknis. Organisasi yang memiliki dua pimpinan tentunya mempunyai kelebihan (sebagai sistem monitoring dan evaluasi antara pimpinan) dan kekurangan (memperpanjang proses koordinasi yang berpotensi menghambat pencapaian tujuan). Menurut penulis, dalam konteks koordinasi akan lebih baik apabila BPBD Kabupaten Purworejo dipimpin secara tunggal, baik pada tataran administratif maupun operasional (teknis) guna meningkatkan efektivitas koordinasi lembaga dan memangkas proses birokrasi. Kedua, berbagai macam pedoman (peraturan dan standar operasional prosedur) yang dimiliki dan digunakan oleh seluruh pihak dalam penanggulangan bencana sebaiknya disosialisasikan secara rutin dan kontinu untuk meningkatkan pemahaman dan meminimalisir ego sektoral masing-masing pihak. Ketiga, guna menghindari terjadinya miskoordinasi seperti yang terjadi pada pihak organisasi masyarakat dan swasta terkait pendirian posko, maka BPBD Kabupaten Purworejo hendaknya melakukan pemetaan para pihak secara berkelanjutan, baik saat kondisi sebelum, sedang, dan setelah terjadinya bencana serta menggunakan wewenangnya secara tegas selaku komando lapangan khususnya secara horizontal.

\section{Daftar Pustaka}

Achyar, E., Schmidt-Vogt, D., \& Shivakoti, G. P. (2015). Dynamics of the MultiStakeholder Forum and its Effectiveness in Promoting Sustainable Forest Fire Management Practices in South Sumatra, Indonesia. Environmental Development, 13, 4-17. doi: 10.1016/j.envdev. 2014.11.002

Amran. (2016). Peningkatan Partisipasi Masyarakat dalam Pengurangan Risiko Bencana Tanah Longsor Melalui Kelompok Kampung Siaga Bencana. PEKSOS: Jurnal 
IImiah Pekerjaan Sosial, 15(1), 139-153. doi: 10.31595/peksos.v15i1.69

Bahadori, M., Khankeh, H. R., Zaboli, R., \& Malmir, I. (2015). Coordination in Disaster: A Narrative Review. International Journal of Medical Reviews, 2(2), 273-281.

Guo, X. \& Kapucu, N. (2015). Network Performance Assessment for Collaborative Disaster Response. Disaster Prevention and Management, 24(2), 201-220. doi: 10.1108/DPM-10-2014-0209

Heksantoro, R. (2018, Mei, 18). Cilacap dan Purworejo Jadi Daerah Paling Rawan Bencana di Jateng. detik.com. Diakses dari https://news.detik.com/beritajawa-tengah/d-3918132/cilacap-danpBahadoriurworejo-jadi-daerah-palingrawan-bencana-di-jateng.

Horney, J., Nguyen, M., Salvesen, D., Tomasco, O., \& Berke, P. (2016). Engaging the public in planning for disaster recovery. International Journal of Disaster Risk Reduction, 17, 33-37. doi: 10.1016/j. ijdrr.2016.03.011

Hustedt, T. \& Danken, T. (2017). Institutional Logics in Inter-Departmental Coordination: Why Actors Agree on A Joint Policy Output. Public Administration, 9(3), 730743. doi: 10.1111/padm.12331

Indonesia Negara Rawan Bencana. (2011, Agustus 10). BBC News Indonesia. Diakses dari Indonesia negara rawan bencana - BBC News Indonesia.

Kaynak, R. \& Tuger, A. T. (2014). Coordination and Collaboration Functions of Disaster Coordination Centers for Humanitarian Logistics. Procedia-Social and Behavioral Sciences, 109, 432-437. doi: 10.1016/j. sbspro.2013.12.486

Kurniawati, C. P. (2015). Kajian Permasalahan Kebijakan Penetapan Status Bencana, Kelembagaan BPBD, dan Pengelolaan Bantuan Pasca Terbitnya UU Nomor 24 Tahun 2007. Jurnal Tata Kelola dan Akuntabilitas Keuangan Negara, 1(1), 95106. doi: 10.28986/jtaken.v1i1.19

Lubis, E. E. \& Wahyudi, F. (2016). Pola Komunikasi Badan Penanggulangan Bencana Daerah Provinsi Riau dalam
Mencegah dan Menanggulangi Bencana Asap di Riau. Jurnal Online Mahasiswa Fakultas IImu Sosial dan IImu Politik Universitas Riau, 3(2), 1-15.

Octorano, D. F. (2015). Pengaruh Koordinasi, Kompetensi dan Disiplin Terhadap Kinerja Pegawai Unit Layanan Pengadaan Kementerian Agama Pusat (ULP Kemenag Pusat). Jurnal MIX, 5(1), 108-123. doi: 10.22441/jurnal_mix

Putra, R. W. (2015). Penyelenggaraan Penanggulangan Bencana Banjir oleh Badan Penanggulangan Bencana Daerah di Kabupaten Kutai Barat. eJournal IImu Pemerintahan, 3( 4), 1940-1950.

Ramdani, E. M. (2015). Koordinasi oleh BPBD dalam Penanggulangan Bencana Banjir di Kabupaten Bandung. Jurnal IImu Administrasi, 12(3), 383-406, doi: 10.31113/jia. v12i3.50

Saputra, E. (2018). Manajemen Komunikasi Badan Penanggulangan Bencana Daerah (BPBD) Terhadap Bencana Banjir di Kabupaten Kampar. Jurnal Online Mahasiswa Fakultas IImu Sosial dan IImu Politik Universitas Riau, 5(1), 1-14.

Saut, P. D. (2018, Februari 23). Ini Daftar BPBD Terbaik Versi BNPB. detik.com. Diakses dari https://m.detik.com/news/ berita/d-3881159/ini-daftar-bpbd-terbaikversi-bnpb.

Gus. (2017, April 17). 90 persen desa di purworejo rawan bencana. krjogja.com. Diakses dari http://www.krjogja.com/web. news/read/30202/90_Persen_Desa_di_ Purworejo_Rawan_Bencana.

Stoner, J. A. F. \& Freeman, E. (1992). Management (Fifth Edition). New Jersey: Prentice Hall, Englewood Cliffs.

Sugiono. (2014). Metode Penelitian Kuantitatif, Kualitatif, dan $R \& D$. Bandung: Alfabeta.

Sukarno, F. (2016). Koordinasi dalam Pengelolaan Objek Wisata Taman Nasional Kayan Mentarang di Desa Tanjung Lapang Kilometer Delapan Kabupaten Malinau. eJournal Pemerintahan Integratif, 4(2), 217-232.

Wicaksono, N. A. (2020, Oktober 22). Purworejo masuk wilayah risiko rawan 
bencana di Jateng. medcom.id. Diakses dari https://www.medcom.id/nasional/ daerah/3NOqy83k-purworejo-masukwilayah-risiko-rawan-bencana-di-jateng.

Wijaya, C. (2017). Perilaku Organisasi. Medan: Lembaga Peduli Pengembangan Pendidikan Indonesia.

Yoseph-Paulus, R. Y., \& Hindmarsh, R. (2016). Addressing Inadequacies of Sectoral Coordination and Local Capacity Building in Indonesia for Effective Climate Change Adaptation. Climate and Development, 10(1), 35-48, doi: 10.1080/17565529.2016.1184609 